\title{
Preparation of RSn(I)-Sn(I)R with Two Unsymmetrically Coordinated Sn(I) Atoms and Subsequent Gentle Activation of $\mathrm{P}_{4}$
}

\author{
Shabana Khan, ${ }^{\dagger}$ Reent Michel, ${ }^{\dagger}$ Johannes M. Dieterich, ${ }_{\S}^{\ddagger}$ Ricardo A. Mata, ${ }^{*, \neq}$ Herbert W. Roesky, ${ }^{*,+}$ \\ Jean-Philippe Demers, ${ }^{\S}$ Adam Lange, ${ }^{\S}$ and Dietmar Stalke, \\ ${ }^{\dagger}$ Institut für Anorganische Chemie, Georg-August-Universität, Tammannstrasse 4, D-37077 Göttingen, Germany \\ ${ }^{\ddagger}$ Institut für Physikalische Chemie, Georg-August-Universität, Tammannstrasse 6, D-37077, Göttingen, Germany \\ ${ }^{\S}$ Max-Planck-Institut für biophysikalische Chemie, Am Faßberg11, D-37077 Göttingen, Germany
}

Supporting Information

ABSTRACT: This article reports the reduction of $[\{2,6-$ $\left.\left.i \mathrm{Pr}_{2} \mathrm{C}_{6} \mathrm{H}_{3} \mathrm{NC}\left(\mathrm{CH}_{3}\right)\right\}_{2} \mathrm{C}_{6} \mathrm{H}_{3} \mathrm{SnCl}\right]$ (1) with potassium graphite to afford a new distannyne $\left[\left\{2,6-i \mathrm{Pr}_{2} \mathrm{C}_{6} \mathrm{H}_{3} \mathrm{NC}\left(\mathrm{CH}_{3}\right)\right\}_{2} \mathrm{C}_{6} \mathrm{H}_{3} \mathrm{Sn}\right]_{2}$ (2) with a $\mathrm{Sn}-\mathrm{Sn}$ bond. The most striking phenomenon of $\mathbf{2}$ is the presence of two differently coordinated $\mathrm{Sn}$ atoms (one is three-coordinated, the other is four-coordinated). The $\mathrm{Sn}-\mathrm{Sn}$

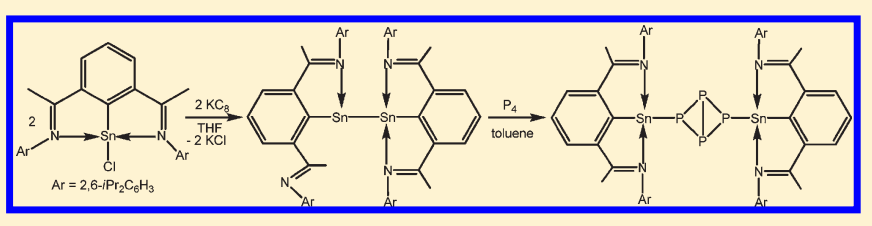
bond length in 2 is 2.8981 (9) $\AA$, which is very close to that of a $\mathrm{Sn}-\mathrm{Sn}$ single bond (2.97-3.06 $)$ ). To elucidate the nature of the $\mathrm{Sn}-\mathrm{Sn}$ bond, DFT calculation is carried out that shows there is no multiple bond character in 2 . Furthermore, the reaction of 2 with white $\mathrm{P}_{4}$ affords the tetraphosphabicylobutane derivative 3 . This is the first example of gentle activation of white phosphorus by a compound with low valent $\mathrm{Sn}$ atoms. Note that, unlike 2, in 3 both $\mathrm{Sn}$ atoms are four-coordinated.

\section{INTRODUCTION}

One of the vital research areas in modern main-group chemistry is focused on the synthesis of heavier group 14 homologues of alkynes, and pursuing their reactivity. The comprehension that steric protection could be employed to overcome the kinetic instability smoothed the progress of the chemistry of low-valent heavier group 14 elements. In recent years a number of alkyne analogues of $\mathrm{Si}, \mathrm{Ge}$, and $\mathrm{Sn}$ have been reported. The remarkable progress in this area is reflected by reviews devoted to this topic. ${ }^{1}$ The first alkyne analogue of tin, namely, dark blue-green distannyne $\left[\mathrm{ArSnSnAr} ; \mathrm{Ar}=2,6-\mathrm{Dipp}_{2} \mathrm{C}_{6} \mathrm{H}_{3}\left(\mathrm{Dipp}=2,6-i \mathrm{Pr}_{2} \mathrm{C}_{6} \mathrm{H}_{3}\right)\right]$ (A), was reported by Power et al. in $2002 .{ }^{2}$ Following this the same group isolated a series of distannynes by altering the Ar ligand through replacement of the $p$-hydrogen of the central aryl ring with various substituents $\left(t \mathrm{Bu}, \mathrm{Cl}, \mathrm{OMe}, \mathrm{SiMe}_{3}, \mathrm{GeMe}_{3}\right) .{ }^{3}$ A new type of intramolecularly coordinated distannyne, $\left[\left\{2,6-\left(\mathrm{Me}_{2} \mathrm{NCH}_{2}\right)_{2^{-}}\right.\right.$ $\left.\left.\mathrm{C}_{6} \mathrm{H}_{3}\right\} \mathrm{Sn}\right]_{2}$ (B), was prepared by Jambor et al. in 2008 . ${ }^{4}$ The isolation of an amidinato stabilized distannyne [ArSnSnAr; $\left.\mathrm{Ar}=4-t \mathrm{BuC}_{6} \mathrm{H}_{4} \mathrm{C}(\mathrm{NDipp})_{2}\right]^{5}$ was reported by Jones et al. using the $\mathrm{Mg}(\mathrm{I})$ dimer $\left[\left\{{ }^{\text {Mes }}(\mathrm{Nacnac}) \mathrm{Mg}\right\}\right]_{2}$, $\left({ }^{\text {Mes }} \mathrm{Nacnac}=\right.$ $\left.\left[(\mathrm{MesNCMe})_{2} \mathrm{CH}\right], \mathrm{Mes}=2,4,6-\mathrm{Me}_{3} \mathrm{C}_{6} \mathrm{H}_{2}\right)$ as a reducing agent. ${ }^{6}$ The bonding in the alkyne analogues of heavier group 14 elements has been the subject of considerable discussion. In contrast to the triple bond of acetylene, which has a bond order of 3 , calculation shows that the bond order in $\mathbf{A}$ is ca. 2, whereas in $\mathbf{B}$ it is about 1 . Therefore, it can be envisaged that two types of alkyne analogues of tin are possible: (a) two $\mathrm{Sn}$ atoms are connected by a triple bond (I) and (b) two $\mathrm{Sn}$ atoms are connected by a $\sigma$-bond and each holds a lone pair of electrons (II) (Scheme 1). However, it is unquestionable that all these alkyne analogues of tin show marked lone pair character and decreasing $\pi$-overlap of the involved atoms.
Scheme 1. Multiply and Singly Bonded Alkyne Analogues of Tin

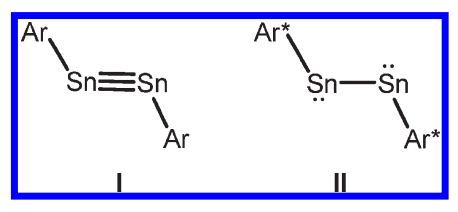

Our formal entry in this chemistry started in 2008 with the isolation of a bis(germylene) $\left(\mathrm{PhC}(\mathrm{N} t \mathrm{Bu})_{2} \mathrm{Ge}\right)_{2},{ }^{8 \mathrm{a}}$ which was followed by the discovery of analogous bis(silylene) $\left(\mathrm{PhC}(\mathrm{N} t \mathrm{Bu})_{2} \mathrm{Si}\right)_{2} \cdot{ }^{8 \mathrm{~b}}$ However, attempts to stabilize the bis(stannylene) with the support of the same amidinato ligand was unsuccessful. ${ }^{8 c}$ The selection of the correct ligand has been critical in the synthesis of these compounds, and it is already known that additional $\mathrm{N}$-donation to stannylenes is advantageous in the synthesis of $\mathrm{Sn}\left(o-\mathrm{C}_{6} \mathrm{H}_{4} \mathrm{PPh}_{2} \mathrm{NSiMe}_{3}\right)_{2}$. Therefore, we turned our attention toward the pincer-based ligand, which has a long history of stabilizing transition metals ${ }^{10}$ due to the firm tridentate coordination mode. Recently Dostál et al. employed successfully the pincer ligand to stabilize monomeric compounds with $\mathrm{Sb}(\mathrm{I})$ and $\mathrm{Bi}(\mathrm{I}) .{ }^{11}$ Accordingly, we treated $\left[\left\{2,6-i \mathrm{Pr}_{2} \mathrm{C}_{6} \mathrm{H}_{3} \mathrm{NC}\left(\mathrm{CH}_{3}\right)\right\}_{2} \mathrm{C}_{6} \mathrm{H}_{3}-\right.$ $\mathrm{SnCl}]$ (1) with $\mathrm{KC}_{8}$ and isolated a new type of bis-stannylene 2 with two unsymmetrically coordinated $\mathrm{Sn}$ atoms in the same framework.

Received: August 10, 2011

Published: September 29, 2011 
Scheme 2. Preparation of Compound 2

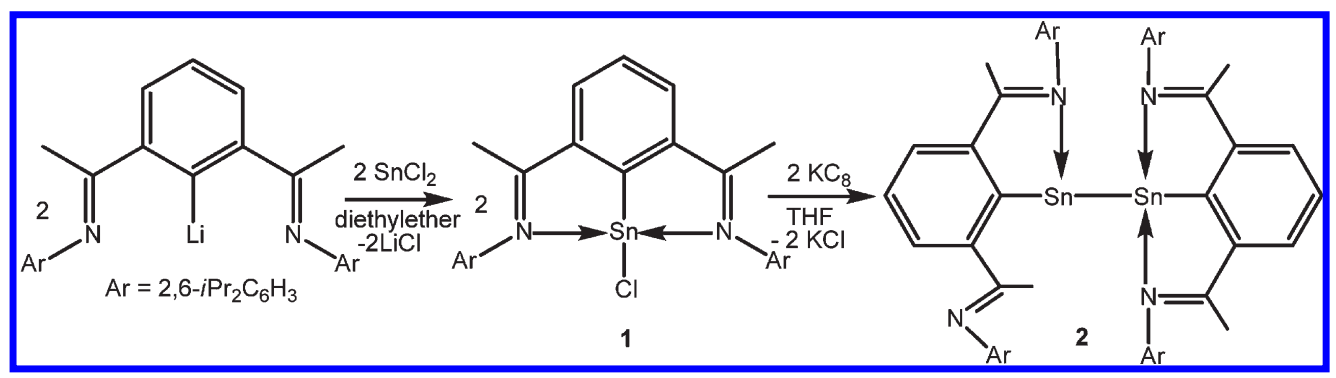

\section{RESULT AND DISCUSSION}

The reduction of 1 with 1 equiv of $\mathrm{KC}_{8}$ in THF afforded the bis(stannylene) derivative 2 in $30 \%$ yield (Scheme 2). Upon reduction, immediately a deep blue color developed, which turned dark green after $14 \mathrm{~h}$ of stirring. The removal of the solvent in vacuum followed by extraction with toluene yielded a dark green solid. Recrystallization of 2 from $n$-pentane at $0{ }^{\circ} \mathrm{C}$ afforded extremely air- and moisture-sensitive dark green crystals of 2 suitable for X-ray crystallography. ${ }^{12}$ Compound 2 crystallizes in the monoclinic space group $P 2_{1} / c$ (Figure 1 ). The most salient feature of $\mathbf{2}$ is the presence of two differently coordinated Sn atoms in the +1 oxidation state. This is the first example of an alkyne analogue of main group elements where both metals are unsymmetrically coordinated. The Sn 1 atom is four-coordinated with distorted tetrahedral geometry and coordinated by two nitrogen atoms ( $\mathrm{N} 3$ and N4) of both the pendant arms with bond lengths for Sn1-N3 and Sn1-N4 of 2.6879(17) and $2.4129(16) \AA$, respectively. The Sn 2 atom is further coordinated to only one nitrogen atom (N2) at a distance of 2.2228(16) $\AA$ and hence adopts a distorted trigonal pyramidal geometry. The $\mathrm{Sn} 2-\mathrm{N} 2$ bond length is the shortest among all of the $\mathrm{Sn}-\mathrm{N}$ interactions. The pendant $\mathrm{N} 1$ is turned away from the tin atom. The coordinated bonding between $\mathrm{N} 2$ and $\mathrm{Sn} 2$ is further verifiable from the two $\mathrm{C}-\mathrm{N}$ double bond lengths, which are almost equal $(1.287(2)$ and $1.303(2) \AA)$. The $\mathrm{Sn}-\mathrm{N}$ bond lengths vary from 2.2207 to $2.6879(17) \AA$ and are in good agreement with those reported in the literature for $\mathrm{N} \rightarrow \mathrm{Sn}$ bonds. ${ }^{4,13}$ The Sn1-Sn2 bond length of 2.8981(9) $\AA$ in 2 is considerably shorter than that of $\mathbf{B}(2.9712(12) \AA)^{4}$ and other reported bis-stannylenes ${ }^{3,5}$ but significantly longer than that of $\mathbf{A}$ (2.6675(4) A). ${ }^{2}$ Because of the two unsymmetrically coordinated $\mathrm{Sn}$ atoms the two $\mathrm{Sn}-\mathrm{Sn}-\mathrm{C}$ bond angles $(\mathrm{C} 49-\mathrm{Sn} 2-\mathrm{Sn} 1=$ $121.26(4)^{\circ}$ and $\left.\mathrm{C} 59-\mathrm{Sn} 2-\mathrm{Sn} 1=96.63(5)^{\circ}\right)$ differ substantially from each other. Compound 2 exhibits a gauche-bent geometry with a torsion angle $\mathrm{C} 49-\mathrm{Sn} 2-\mathrm{Sn} 1-\mathrm{C} 59$ of $83.36(7)^{\circ}$.

To gain some insight into the $\mathrm{Sn}-\mathrm{Sn}$ bonding, quantum chemical calculations were performed on 2 . The structure was optimized at the B3LYP/def2-SVP level of theory, ${ }^{14 a, b}$ combined with the relativistic small core (Stuttgart-Köln ECP) for Sn. ${ }^{14 c}$ All structure optimizations in this work were carried out with the ORCA program package. ${ }^{15 a}$ Single point calculations were performed with Molpro2010.1. ${ }^{15 b}$ The optimized structure reveals a $\mathrm{Sn}-\mathrm{Sn}$ bond distance of $3.046 \AA$, slightly longer than that of the refined crystal structure but in fairly good agreement taking into account the level of theory. An overestimation of the bond length is also expected, since our model is lacking the description of dispersion interactions. This should lead to an

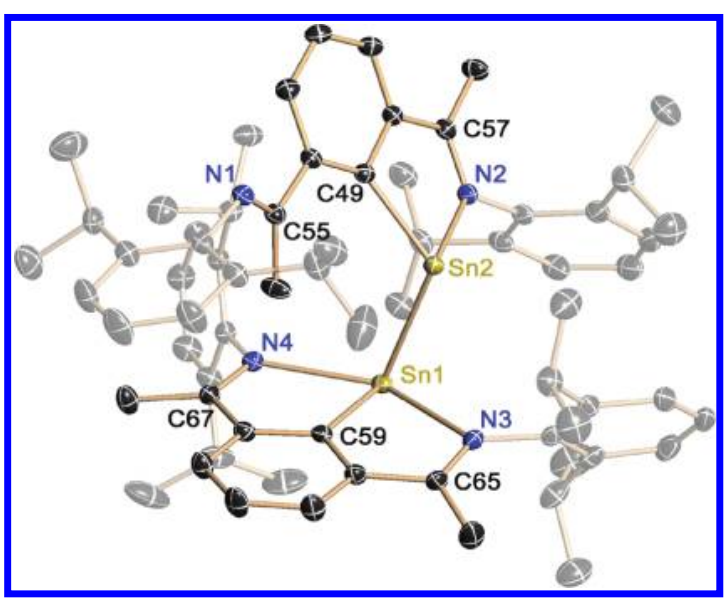

Figure 1. Molecular structure of 2. Anisotropic displacement parameters are depicted at the $50 \%$ probability level. Hydrogen atoms, disorder of $i \mathrm{Pr}$ groups, and lattice $n$-pentane were omitted and 2,6${ }_{i} \mathrm{Pr}_{2} \mathrm{C}_{6} \mathrm{H}_{3}$ groups appear transparent for clarity. Selected bond distances ( $)$ and bond angles (deg): Sn1-Sn2 2.8981(9), Sn1-N3 2.6879(17), Sn1-N4 2.4129(16), Sn2-N2 2.2228(16), Sn1-C59 2.1575(18), Sn2-C49 2.1880(19), N1-C55 1.280(2), N2-C57 1.309(2), N3-C65 1.287(2), N4-C67 1.303(2); C49-Sn2-Sn1 121.26(4), N2-Sn2-Sn1 99.87(4), N4-Sn1-Sn2 105.11(4), N3-Sn1-Sn2 75.42(4), N4-Sn1-N3 141.01(5), N4-Sn1-C59 72.88(6), N3-Sn1-C59 68.41(6), C59-Sn1-Sn2 96.63(5), C49-Sn2-N2 76.72(6), C59-Sn1-Sn2-C49 83.36(7).

increased repulsion of the bulky groups, moving the $\mathrm{Sn}$ atoms further apart. Empirical dispersion corrected functionals could be used to circumvent this problem. ${ }^{16}$ However, we found that the optimization convergence was significantly deteriorated with the use of B3LYP-D. This is linked to the appearance of shallow potential wells with the added dispersion corrections. Therefore, we decided to neglect such corrections. The B3LYP/def2-TZVP electronic density of $\mathbf{2}$ was also calculated and used for a natural bond orbital (NBO) analysis. ${ }^{17}$ We find that a lone pair is located at each of the $\mathrm{Sn}$ atoms (populations of 1.89 and 1.85 electrons). By observing the natural atomic orbital (NAO) contributions to each of the pairs, one finds that they are essentially of $s$-character ( $82-84 \%$, with only $16-18 \%$ p-character; see isosurface plot for the NBOs in the Supporting Information).

Another question arises about the asymmetric coordination of the $\mathrm{Sn}-\mathrm{Sn}$ bond. To achieve further insight, one would have to compare 2 with a model compound where both $\mathrm{Sn}$ atoms are four-coordinated. However, due to the bulky groups around the tin atoms, we found it impossible to accommodate a bond between N1 and the Sn2. Instead, a truncated model structure 


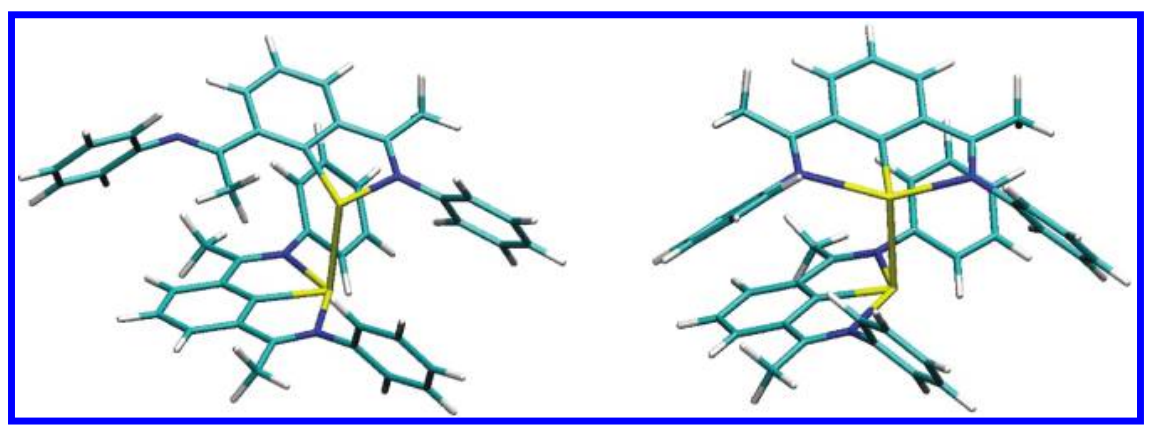

Figure 2. Model structures of 2 optimized at the B3LYP/def2-SVP level of theory, with (3-4) coordination (left) and (4-4) coordination (right).

was generated by removing the $i$ Pr groups. From this model structure, two isomers were optimized at the B3LYP/def2-SVP level of theory. In the first structure we kept the coordination pattern of 2 . In the second isomer, the N1-C55-C49-Sn2 dihedral angle was rotated to build a coordination between N1 and $\mathrm{Sn} 2$. Both structures are shown in Figure 2. The $\mathrm{Sn}-\mathrm{Sn}$ bond distance in the 3-and 4-coordinated model is in agreement with that found in 2 ( $3.040 \AA$ compared to $3.046 \AA$ ), showing that the modifications introduced have only a marginal impact on the $\mathrm{Sn}-\mathrm{Sn}$ bonding. Moreover it is feasible to compare the hypothetical 4-4 case and observe the force of the coordination on the $\mathrm{Sn}-\mathrm{Sn}$ bond. We find that the changes are minimal; the bond length is increased by only $0.003 \AA$. Therefore, the asymmetrical coordination does not seem to strengthen or weaken the $\mathrm{Sn}-\mathrm{Sn}$ bond. Furthermore, comparing the energies of the two models at the B3LYP/def2-TZVP level of theory, we find that the 4-4 coordination is favored by $7.6 \mathrm{kcal} / \mathrm{mol}$. This indicates that the asymmetrical coordination in $\mathbf{2}$ is due to steric strain introduced by the $i \operatorname{Pr}$ groups and unrelated to any strengthening of the $\mathrm{Sn}-\mathrm{Sn}$ bond.

The ${ }^{1} \mathrm{H}$ and ${ }^{13} \mathrm{C}$ NMR data confirm the presence of two chemically different environments for 2,6 -bis $\left[N-\left(2^{\prime}, 6^{\prime}\right.\right.$ diisopropylphenyl)ketimino] phenyl moiety and methyl group attached to imino group in 2 . However, despite numerous attempts, an ${ }^{119} \mathrm{Sn}$ NMR resonance could not be detected in solution. This is presumably due to the broadening of resonance to undetectable level caused by the chemical shift anisotropies induced by the tin environment which was also mentioned by Power et al. ${ }^{2}$ The UV-vis spectrum of $\mathbf{2}$ in toluene shows three absorption maxima at 424.8, 457.3, and $561.3 \mathrm{~nm}$ and are in line with the reported compounds. ${ }^{2-5}$ The EI-MS spectrum exhibits the most abundant peak with highest relative intensity at $m / z 599$ that indicates half the fragment of the molecule. Furthermore the structure of 2 was strongly supported by ${ }^{119}$ Sn CP-MAS NMR investigations.

Two highly anisotropic resonances were detected in the ${ }^{119} \mathrm{Sn}$ solid-state NMR (Figure 3). CP-MAS experiments carried at two MAS frequencies identified the isotropic chemical shifts at 134 and $115 \mathrm{ppm}$ (referenced to $\mathrm{Me}_{4} \mathrm{Sn}$ ). The cross-polarization build-up curves confirm that both tin sites are nonprotonated. Maximal intensity is reached after more than $5 \mathrm{~ms}$, indicating a large distance separation between tin and the nearest proton. The structure of $\mathbf{2}$ is further supported by the detection of one-bond carbon-tin $J$ couplings on the two most downfield ${ }^{13} \mathrm{C}$ resonances, which correspond to the carbons covalently bound to tin (see Supporting Information, Figure S1). The magnitude of the $J$ couplings ( 433 and $323 \mathrm{~Hz}$ ) are in agreement with values in the literature for one-bond carbon - tin coupling. 9,18

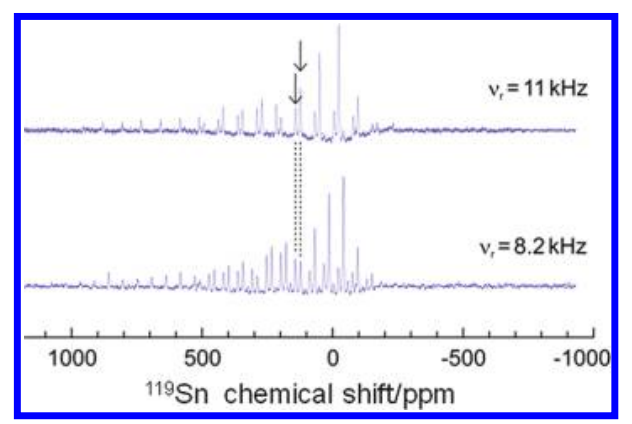

Figure 3. ${ }^{119} \mathrm{Sn}$ solid-state NMR cross-polarization spectra of bis(stannylene) 2. The spectra were recorded at 8.2 and $11 \mathrm{kHz}$ MAS on a $9.4 \mathrm{~T}$ spectrometer. Isotropic chemical shifts are indicated by arrows.

In a report from 2010, entitled "Main-group elements as transition metals" Power pointed out that main group elements in lower oxidation states show remarkable resemblance to transition metals due to the presence of frontier orbitals with small energy separations. ${ }^{19}$ As a result, it is expected that, like transition metals, compounds with low-valent group 14 elements can also activate $\mathrm{P}_{4}$, and indeed there are recent reports on the activation of $\mathrm{P}_{4}$ by carbenes ${ }^{20}$ and silylenes. ${ }^{21}$ Although the reactions of $\mathrm{P}_{4}$ with tetraphenyl tin or dimethyl tin hydride were known, ${ }^{22}$ so far no gentle activation of $\mathrm{P}_{4}$ with a compound containing low valent $\mathrm{Ge}$ or $\mathrm{Sn}$ has been demonstrated. In line with this observation Driess et al. mentioned that the germanium analogue of $N$ hetrocyclic silylene [LGe, $\left(\mathrm{L}=\mathrm{CH}\left[\left(\mathrm{C}=\mathrm{CH}_{2}\right) \mathrm{CMe}\right][\mathrm{N}(2,6-\right.$ $\left.\left.i \mathrm{Pr}_{2} \mathrm{C}_{6} \mathrm{H}_{3}\right)\right]_{2}$ )] is resistant toward $\mathrm{P}_{4}$ even in boiling toluene owing to the lower reduction potential of $\mathrm{Ge}$ versus $\mathrm{Si}$ (inert-pair effect). ${ }^{21 a}$ The only example of $\mathrm{P}_{4}$ activation where a compound with low valent $\mathrm{Sn}$ was used is the synthesis of a species with composition of $\mathrm{Sn}_{4} \mathrm{P}_{3}$. This compound was obtained by treatment of $\mathrm{SnCl}_{2}$ with $\mathrm{KBH}_{4}$ in the presence of white phosphorus under hydrothermal conditions (EtOH, $160{ }^{\circ} \mathrm{C}$, autoclave, $\left.10 \mathrm{~h}\right) .^{23}$ Although several reactions of distannynes with various organic substrates have been reported, ${ }^{24,25}$ surprisingly no reaction with phosphorus has been mentioned so far. As a result, there is a high quest for the mild activation of $\mathrm{P}_{4}$ by a compound with low valent $\mathrm{Sn}$ atoms. Herein, we show for the first time activation of the $\mathrm{P}_{4}$ tetrahedron by compound 2 with low valent $\mathrm{Sn}(\mathrm{I})$ atoms.

Treatment of 2 with $\mathrm{P}_{4}$ in toluene in a 1:1 molar ratio at ambient temperature provided a dark purple solution (Scheme 3 ). The removal of the solvent under vacuum followed by recrystallization in $n$-pentane afforded purple crystals of 3 suitable for single crystal X-ray structural determination. The ${ }^{1} \mathrm{H}$ NMR spectrum of 3 shows four doublets for 48 protons of the $i \operatorname{Pr}$ groups $(\delta=0.90$, $0.99,1.20$, and 1.27 ppm respectively). A resonance for 12 methyl 
Scheme 3. Preparation of Compound 3
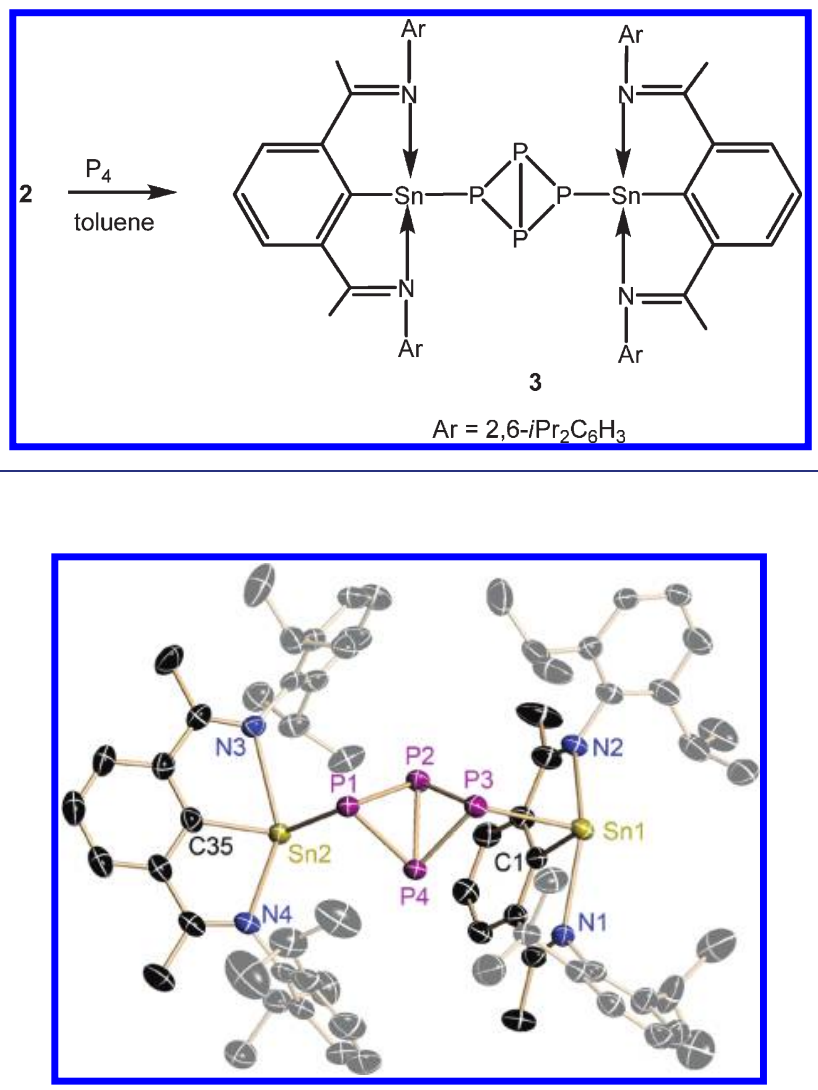

Figure 4. Molecular structure of compound 3. Anisotropic displacement parameters are depicted at the $50 \%$ probability level. Hydrogen atoms were omitted for clarity. Selected bond distances $(\AA)$ and bond angles (deg): Sn1-P3 2.7189(9), Sn2-P1 2.6096(9), P1-P2 2.2274(12), P2-P3 2.2236(12), P1-P4 2.2210(12), P4-P3 2.2248(12), P2-P4 2.1528(11), Sn2-N3 2.519(2), Sn2-N4 2.456(3), Sn1-N2 2.492(2), Sn1-N1 2.471(2); C35-Sn2-P1 104.48(9), N3-Sn2-P1 87.18(6), N4-Sn2-P1 91.46(7), N2-Sn1-P3 92.63(7), N1-Sn1-P3 89.88(6), P2-P1-P4 57.89(4), P1-P4-P3 83.02(4), P4-P3-P2 57.89(4), P3-P2-P1 82.90(4), P3-P2-P4 61.08(4), P3-P4-P2 61.03(4), P1-P4-P2 61.21(4), P1-P2-P4 60.91(4).

protons appears as a sharp singlet $(\delta=1.94 \mathrm{ppm})$. Two septets for $\mathrm{CHMe}_{2}$ protons resonate at $\delta=2.75$ and $3.00 \mathrm{ppm}$. The ${ }^{119} \mathrm{Sn}$ NMR spectrum exhibits a broad resonance at $\delta=703.33 \mathrm{ppm}$. The ${ }^{31} \mathrm{P}$ NMR spectrum of 3 displays two resonances $(\delta=-97.70$ and $-327.32 \mathrm{ppm}$ ) confirming the presence of two chemically different phosphorus. The phosphorus attached to tin appears at $\delta=-97.70 \mathrm{ppm}$ as a triplet $\left({ }^{1} J\left({ }^{31} \mathrm{P}-{ }^{31} \mathrm{P}\right)=158 \mathrm{~Hz}\right)$ with tin satellites. Another phosphorus atom associated to the $\mathrm{P}_{4}$ tetrahedron appears as a sharp triplet at $\delta=-327.32 \mathrm{ppm}\left(\left({ }^{1} J\left({ }^{31} \mathrm{P}-{ }^{31} \mathrm{P}\right)=\right.\right.$ $161 \mathrm{~Hz})$. In the EI-MS spectrum the most abundant peak was observed at $m / z 976$, which corresponds to the fragment after the loss of 8 iPr groups.

The constitution of 3 was determined by single crystal X-ray studies (Figure 4). Compound 3 crystallizes in the monoclinic space group $P 2_{1} / c{ }^{12}$ The molecular structure reveals the insertion of one $\mathrm{P}_{4}$ tetrahedron into the $\mathrm{Sn}-\mathrm{Sn}$ bond of 2 to form a butterfly-like bicyclo[1.1.0] tetraphosphabutane moiety via selective cleavage of a single $\mathrm{P}-\mathrm{P}$ bond in the $\mathrm{P}_{4}$ tetrahedron. Similar butterfly-like molecules with a tetraphosphabicyclobutane skeleton have been reported, ${ }^{26}$ but not with heavier group 14 elements. Therefore, with the synthesis of 3 (cf. Scheme 3), the selective activation of one of the six $\mathrm{P}-\mathrm{P}$ bonds in $\mathrm{P}_{4}$ by a heavier group 14 element has been achieved for the first time. It is noteworthy to mention that in 3 both tin atoms are symmetrical and four-coordinated and possess distorted tetrahedral geometry. The $\mathrm{Sn}-\mathrm{P}$ bond lengths in 3 of 2.7189(9) and 2.6096(9) $\AA$ fall in the range of those reported in literature for $\mathrm{Sn}-\mathrm{P}$ single bonds. ${ }^{22,27,28}$ The average $\mathrm{P}-\mathrm{P}$ bond length of the peripheral phosphorus atoms $(2.2242 \AA)$ is very close to white $\mathrm{P}_{4}(2.21 \AA)$ itself and other tetraphosphabicyclobutane derivatives, ${ }^{26,29}$ whereas the bridgehead $\mathrm{P} 2-\mathrm{P} 4$ bond length is 2.1528(11) A. The $\mathrm{Sn}-\mathrm{N}$ bond distances vary between 2.456 (3) $\AA$ for Sn2-N4 to 2.519(2) $\AA$ for Sn2-N3 and are similar to the $\mathrm{S} n-\mathrm{N}$ distances observed for 2 or reported for pincer-based bis(stannylene) B. ${ }^{4}$ The $\mathrm{P} 1-\mathrm{P} 2-\mathrm{P} 3$ and $\mathrm{P} 1-\mathrm{P} 4-\mathrm{P} 3$ angles $\left[82.90(4)^{\circ}, 83.02(4)^{\circ}\right]$ are significantly larger than the intraring $\mathrm{P}-\mathrm{P}-\mathrm{P}$ angles, which are slightly deviated from expected $60^{\circ}$ $\left[57.89(4)-61.21(4)^{\circ}\right]$. The P1 and P3 atoms exhibit trigonalpyramidal geometry. The $\mathrm{P} 3-\mathrm{P} 2-\mathrm{P} 4-\mathrm{P} 1$ torsion angle $\left(98.41(5)^{\circ}\right)$ is similar to the folding angles reported for the 1,4- $\mathrm{R}_{2} \mathrm{P}_{4}$ compounds $\left(92.9-100.4^{\circ}\right)\left(\mathrm{R}=\mathrm{N}\left(\mathrm{SiMe}_{3}\right)_{2}{ }^{29 \mathrm{a}} 2,4,6-\right.$ $t \mathrm{Bu}_{3} \mathrm{C}_{6} \mathrm{H}_{2}{ }^{29 \mathrm{~b}}\left\{\left(\mathrm{Cp}^{\prime}\right)(\mathrm{CO})_{2} \mathrm{Fe}\right\}\left(\mathrm{Cp}^{\prime}=1,2,4-t \mathrm{Bu}_{3} \mathrm{C}_{5} \mathrm{H}_{2}\right),{ }^{26 \mathrm{a}}$ $\left.\mathrm{P}\left\{\mathrm{N}\left(\mathrm{SiMe}_{3}\right)_{2}\right\}_{2},{ }^{28 \mathrm{~b}} 2,6-\mathrm{Dipp}_{2} \mathrm{C}_{6} \mathrm{H}_{3}\right]^{28}$

\section{CONCLUSION}

In summary, we have synthesized a new pincer based bisstannylene with two unsymmetrically coordinated $\mathrm{Sn}(\mathrm{I})$ atoms. Computational studies show that this asymmetry is due to steric crowding and has virtually no impact on the $\mathrm{Sn}(\mathrm{I})-\mathrm{Sn}(\mathrm{I})$ bonding. The $\mathrm{Sn}-\mathrm{Sn}-\mathrm{C}$ bending is not induced by a stereochemically active lone pair as it has predominantly s-character. Reminiscent of d-block metal complexes and $N$-heterocyclic carbene and silylene, this new compound has the ability to activate $\mathrm{P}_{4}$ under ambient condition. This is the first example of phosphorus activation by a $\mathrm{Sn}(\mathrm{I})$ compound.

\section{EXPERIMENTAL SECTION}

All reactions and handling of reagents were performed under an atmosphere of dry nitrogen or argon using standard Schlenk techniques or a glovebox where the $\mathrm{O}_{2}$ and $\mathrm{H}_{2} \mathrm{O}$ levels were usually kept below 1 ppm. Solvents were purified with the M-Braun solvent drying system. Solution NMR spectra were recorded on Bruker Avance 200, Bruker Avance 300, and Bruker Avance $500 \mathrm{MHz}$ NMR spectrometers. Deuterated NMR solvent $\mathrm{C}_{6} \mathrm{D}_{6}$ was dried by stirring for 2 days over $\mathrm{Na} / \mathrm{K}$ alloy followed by distillation in vacuum and degassed. EI-MS spectra were obtained with a Finnigan MAT 8230 or a Varian MAT CH5 instrument $(70 \mathrm{eV})$ by EI-MS methods. Elemental analyses were performed by the Analytisches Labor des Instituts für Anorganische Chemie der Universität Göttingen.

Synthesis of 1. $n \mathrm{BuLi}(8 \mathrm{~mL}, 20 \mathrm{mmol}, 2.5 \mathrm{M}$ solution in $n$-hexane) was added to a stirred solution of 2,6-bis $\left[N\right.$ - $\left(2^{\prime}, 6^{\prime}\right.$-diisopropylphenyl)ketimino]phenyl-1-bromide (5.59 g, $10 \mathrm{mmol})$ in $\mathrm{Et}_{2} \mathrm{O}(90 \mathrm{~mL})$ at $-60{ }^{\circ} \mathrm{C}$. The mixture turned to deep red and was stirred for additional $1 \mathrm{~h}$ at this temperature. This solution was then added to a precooled $\left(-60{ }^{\circ} \mathrm{C}\right)$ solution of $\mathrm{SnCl}_{2}(1.90 \mathrm{~g}, 10 \mathrm{mmol})$ in $\mathrm{Et}_{2} \mathrm{O}(50 \mathrm{~mL})$, and the reaction mixture was allowed to warm to room temperature gradually and stirred for additional $12 \mathrm{~h}$. The solution was filtered through Celite and concentrated to ca. one-third. Concentration and storing of the solution at $0{ }^{\circ} \mathrm{C}$ in a freezer afforded orange-yellow crystals of $\mathbf{1}(2.00 \mathrm{~g}$, $31.05 \%) .{ }^{1} \mathrm{H} \mathrm{NMR}\left(200 \mathrm{MHz}, \mathrm{C}_{6} \mathrm{D}_{6}, 25^{\circ} \mathrm{C}\right) \delta 0.90\left(\mathrm{~m}, 12 \mathrm{H}, \mathrm{CH}_{3}\right), 1.30$ $\left(\mathrm{m}, 12 \mathrm{H}, \mathrm{CH}_{3}\right), 1.94\left(\mathrm{~s}, 6 \mathrm{H}, \mathrm{CH}_{3}-\mathrm{C}=\right), 2.92-3.19$ (m, 4H, $\left.\mathrm{CH}-\right)$, 6.90-7.70 (m, 9H, Ph) ppm; ${ }^{119} \mathrm{Sn}$ NMR $\left(\mathrm{C}_{6} \mathrm{D}_{6}, 111.92 \mathrm{MHz}, 25^{\circ} \mathrm{C}\right)$ 
Table 1. Crystallographic Data

\begin{tabular}{|c|c|c|}
\hline & $2 \cdot \mathrm{C}_{5} \mathrm{H}_{12}$ & 3 \\
\hline$a[\AA]$ & $16.411(6)$ & $14.644(2)$ \\
\hline$b[\AA]$ & $16.426(6)$ & $17.463(2)$ \\
\hline$c[\AA]$ & $25.192(9)$ & $26.602(2)$ \\
\hline$\alpha[\operatorname{deg}]$ & 90 & 90 \\
\hline$\beta[\operatorname{deg}]$ & $94.40(2)$ & $104.48(2)$ \\
\hline$\gamma[\operatorname{deg}]$ & 90 & 90 \\
\hline$V$ & $6771(4)$ & $6586.8(13)$ \\
\hline$Z$ & 4 & 4 \\
\hline$\rho\left[\mathrm{Mg} / \mathrm{m}^{3}\right]$ & 1.245 & 1.332 \\
\hline$\mu\left[\mathrm{mm}^{-1}\right]$ & 0.780 & 0.897 \\
\hline $\mathrm{F}(000)$ & 2656 & 2728 \\
\hline$\theta$ range for data colln $[\mathrm{deg}]$ & $1.24-27.86$ & $1.41-26.04$ \\
\hline \multirow[t]{3}{*}{ index range } & $-21 \leq h \leq 21$ & $-18 \leq h \leq 18$ \\
\hline & $-21 \leq k \leq 21$ & $-21 \leq k \leq 21$ \\
\hline & $-33 \leq l \leq 33$ & $-32 \leq l \leq 32$ \\
\hline refl collected & 177456 & 86017 \\
\hline indep refl & 16126 & 12981 \\
\hline max, min transmis. & $0.7456,0.6971$ & $1.0000,0.8843$ \\
\hline data/restraints/parameters & $16126 / 361 / 851$ & $12981 / 512 / 827$ \\
\hline goodness of fit on $F^{2}$ & 1.042 & 1.072 \\
\hline final R-indices $[I>2 \sigma(I)]$ & $\begin{aligned} R_{1} & =0.0257, \mathrm{w} R_{2} \\
& =0.0561\end{aligned}$ & $\begin{aligned} R_{1} & =0.0374, \mathrm{w} R_{2} \\
& =0.0871\end{aligned}$ \\
\hline final $R$-indices (all data) & $\begin{aligned} R_{1} & =0.0358, \mathrm{w} R_{2} \\
& =0.0609\end{aligned}$ & $\begin{aligned} R_{1} & =0.0541, \mathrm{w} R_{2} \\
& =0.0981\end{aligned}$ \\
\hline $\begin{array}{l}\text { largest diff peak and } \\
\quad \text { hole }\left[\mathrm{e} \AA^{-3}\right]\end{array}$ & 0.650 and -0.487 & 2.311 and -0.857 \\
\hline CCDC number & 833290 & 833291 \\
\hline
\end{tabular}

$\delta-20$ ppm. EI-MS: $m / z 634\left[\mathrm{M}^{+}\right]$(100\%). Anal. Calcd for $\mathrm{C}_{34} \mathrm{H}_{43} \mathrm{ClN}_{2} \mathrm{Sn}_{2}$ (634.21): C, 64.42; H, 6.84; N, 4.42. Found: C, 63.96; H, 6.12; N, 4.10.

Synthesis of 2 . To the mixture of $\mathbf{1}(1.27 \mathrm{~g}, 2.00 \mathrm{mmol})$ and $\mathrm{KC}_{8}$ $(0.270 \mathrm{~g}, 2.00 \mathrm{mmol})$ at $-60^{\circ} \mathrm{C}$ was added THF $(50 \mathrm{~mL})$, and the color of the solution immediately changed from orange to dark green. The reaction mixture was stirred for $12 \mathrm{~h}$. The solvent was removed under reduced pressure, and the residue was extracted with toluene $(30 \mathrm{~mL})$. Recrystallization in $n$-pentane $(25 \mathrm{~mL})$ at $0{ }^{\circ} \mathrm{C}$ in a freezer afforded dark green crystals of $2 \cdot \mathrm{C}_{5} \mathrm{H}_{12}(0.30 \mathrm{~g}, 25 \%) .{ }^{1} \mathrm{H}$ NMR $\left(500 \mathrm{MHz}, \mathrm{C}_{6} \mathrm{D}_{6}\right.$, $\left.25^{\circ} \mathrm{C}\right) \delta 0.89-1.16\left(\mathrm{~m}, 24 \mathrm{H}, \mathrm{CH}_{3}\right), 1.30\left(\mathrm{~d}, 24 \mathrm{H}, \mathrm{CH}_{3}\right), 1.85(\mathrm{~s}, 3 \mathrm{H}$, $\mathrm{CH}_{3}-\mathrm{C}=$ ), 1.97 (s, 9H, $\mathrm{CH}_{3}-\mathrm{C}=$ ), 2.77 (sept, 4H, $\mathrm{CH}-$ ), 2.95 (sept, $2 \mathrm{H}$, $\mathrm{CH}-$ ), 3.29 (sept, 2H, CH-), 7.02-7.51 (m, 18H, Ph) ppm; ${ }^{13} \mathrm{C}\left\{{ }^{1} \mathrm{H}\right\}$ $\operatorname{NMR}\left(125.75 \mathrm{MHz}, \mathrm{C}_{6} \mathrm{D}_{6}, 25^{\circ} \mathrm{C}\right) \delta 14.23\left(=\mathrm{C}-\mathrm{CH}_{3}\right), 18.23\left(=\mathrm{C}-\mathrm{CH}_{3}\right)$, $20.11,22.94,23.59,24.07,24.45,25.33,25.39,26.04,\left(\mathrm{CH}_{3}\right), 28.72$, $28.88,34.38(-\mathrm{CH}), 123.31,123.61,123.80,124.35,124.52,125.96$, $138.36,140.56,142.66,143.38,143.69,146.86(\mathrm{Ph}), 169.78\left(-\mathrm{C}=\mathrm{CH}_{3}\right)$, $186.32\left(C_{\text {ipso }}\right)$ ppm; ${ }^{119} \mathrm{Sn} \mathrm{NMR}\left(\mathrm{C}_{6} \mathrm{D}_{6}, 111.92 \mathrm{MHz}, 25^{\circ} \mathrm{C}\right)$ we could not observe any signal in solution. EI-MS: $m / z 599\left[\mathrm{M}^{+}-\mathrm{C}_{34} \mathrm{H}_{43} \mathrm{~N}_{2} \mathrm{Sn}\right]$ (100\%). For the elemental analysis $2 \cdot \mathrm{C}_{5} \mathrm{H}_{12}$ was dried under vacuum overnight to remove 1 molecule of $n$-pentane. Anal. Calcd for $\mathrm{C}_{68} \mathrm{H}_{86} \mathrm{~N}_{4} \mathrm{Sn}_{2}$ (1198.49): C, 68.24; H, 7.24; N, 4.68. Found: C, 68.11; H, 7.01; $\mathrm{N}, 4.43$.

Synthesis of 3 . To a mixture of $2(0.300 \mathrm{~g}, 0.25 \mathrm{mmol})$ and $\mathrm{P}_{4}$ $(0.031 \mathrm{~g}, 0.25 \mathrm{mmol})$ was added toluene $(40 \mathrm{~mL})$ at room temperature. Immediately after addition, the reaction mixture turned to deep purple in color. The resulting mixture was stirred for additional $2 \mathrm{~h}$ at room temperature and evaporated under reduced pressure. The residue was extracted with $n$-pentane $(30 \mathrm{~mL})$, and the deep purple filtrate was concentrated to about $5 \mathrm{~mL}$ and stored at $-32{ }^{\circ} \mathrm{C}$ in a freezer to afford dark colored crystals of $3(0.18 \mathrm{~g}, 54.3 \%) .{ }^{1} \mathrm{H}$ NMR $\left(500 \mathrm{MHz}, \mathrm{C}_{6} \mathrm{D}_{6}, 25^{\circ} \mathrm{C}\right) \delta 0.90\left(\mathrm{~d}, 12 \mathrm{H}, \mathrm{CH}_{3}\right), 0.99\left(\mathrm{~d}, 12 \mathrm{H}, \mathrm{CH}_{3}\right)$, $1.20\left(\mathrm{~d}, 12 \mathrm{H}, \mathrm{CH}_{3}\right), 1.27$ (d, $\left.12 \mathrm{H}, \mathrm{CH}_{3}\right), 1.94\left(\mathrm{~s}, 12 \mathrm{H}, \mathrm{CH}_{3}-\mathrm{C}=\right)$, 2.70-2.87 (m, 4H, CH-), 2.99-3.12 (m, 4H, CH-), 7.04-7.71 (m, $18 \mathrm{H}, \mathrm{Ph}) \mathrm{ppm} ;{ }^{13} \mathrm{C}\left\{{ }^{1} \mathrm{H}\right\}$ NMR $\left(125.75 \mathrm{MHz}, \mathrm{C}_{6} \mathrm{D}_{6}, 25{ }^{\circ} \mathrm{C}\right) \delta 17.82$ $\left(=\mathrm{C}-\mathrm{CH}_{3}\right), 23.87,24.04,24.67,25.11\left(\mathrm{CH}_{3}\right), 28.07,28.05(-\mathrm{CH})$, 123.89, 124.01, 125.84, 128.5, 130.06, 138.76, 139.88, $143.69(P h)$, $171.69\left(-\mathrm{C}=\mathrm{CH}_{3}\right), 182.34\left(C_{\text {ipso }}\right) \mathrm{ppm} ;{ }^{31} \mathrm{P} \mathrm{NMR}\left(121.5 \mathrm{MHz}, \mathrm{C}_{6} \mathrm{D}_{6}\right.$, $\left.25{ }^{\circ} \mathrm{C}\right) \delta-97.70\left({ }^{1} J\left({ }^{31} \mathrm{P}-{ }^{31} \mathrm{P}\right)=158 \mathrm{~Hz}\right),-327.32 \mathrm{ppm}\left(\left({ }^{1} J-\right.\right.$ $\left.\left({ }^{31} \mathrm{P}-{ }^{31} \mathrm{P}\right)=161 \mathrm{~Hz}\right) ;{ }^{119} \mathrm{Sn} \operatorname{NMR}\left(\mathrm{C}_{6} \mathrm{D}_{6}, 111.92 \mathrm{MHz}, 25{ }^{\circ} \mathrm{C}\right)$ $\delta+703.33$ ppm. EI-MS: $m / z 976\left[\mathrm{M}^{+}-8 i \mathrm{Pr}\right](100 \%)$. Anal. Calcd for $\mathrm{C}_{68} \mathrm{H}_{86} \mathrm{~N}_{4} \mathrm{P}_{4} \mathrm{Sn}_{2}$ (1320.75): C, 61.84; H, 6.56; N, 4.24. Found: C, 61.19; H, 6.11; N, 4.58 .

Crystal Data for 2 and 3. Shock cooled crystals were selected and mounted under nitrogen atmosphere using the X-TEMP2. The data of 2 and 3 were measured on an INCOATEC Mo Microsource with Quazar mirror optics and a Smart APEX II Ultra detector on a D8 goniometer and are summarized in Table $1 .{ }^{30}$ The diffractometers were equipped with a low temperature device and used Mo K $\alpha$ radiation, $\lambda=0.71073 \AA$. The data sets were integrated with SAINT, ${ }^{31}$ and an empirical absorption (SADABS) was applied. ${ }^{32}$ The structures were solved by direct methods (SHELXS-97) and refined by full-matrix leastsquares methods against $F^{2}$ (SHELXL-97). ${ }^{33}$ All non-hydrogen-atoms were refined with anisotropic displacement parameters. The hydrogen atoms were refined isotropically on calculated positions using a riding model with their $U_{\text {iso }}$ values constrained to equal to 1.5 times the $U_{\text {eq }}$ of their pivot atoms for terminal $\mathrm{sp}^{3}$ carbon atoms and 1.2 times for all other carbon atoms. Disordered moieties were refined using bond length restraints and isotropic displacement parameters restraints. Crystallographic data (excluding structure factors) for the structures reported in this paper have been deposited with the Cambridge Crystallographic Data Center. The crystal data are available from The Cambridge Crystallographic Data Centre via www.ccdc.cam.ac.uk/ data_request/cif.

\section{ASSOCIATED CONTENT}

S Supporting Information. CIF files of $\mathbf{2}$ and 3, solid state NMR and computational details of 2 . This material is available free of charge via the Internet at http://pubs.acs.org.

\section{AUTHOR INFORMATION}

\section{Corresponding Author}

hroesky@gwdg.de; dstalke@chemie.uni-goettingen.de; rmata@ gwdg.de

\section{ACKNOWLEDGMENT}

H.W.R. thanks the Deutsche Forschungsgemeinschaft (DFG RO 224/55-3). S.K. is indebted to Deutscher Akademischer Austausch Dienst for a research fellowship. J.-P.D. thanks NSERC of Canada for a scholarship. D.S. is grateful for funding from the DFG Priority Programme 1178, the DNRF funded Center for Materials Crystallography (CMC) for support, and the Land Niedersachsen for providing a fellowship in the Catalysis for Sustainable Synthesis (CaSuS) Ph.D. program. A.L. thanks the support of the Deutsche Forschungsgemeinschaft for Emmy Noether Fellowship.

This paper is dedicated to Professor Robert West. 


\section{REFERENCES}

(1) For recent reviews, see: (a) Power, P. P. Chem. Rev. 1999, 99, 3463-3504. (b) Power, P. P. Chem. Commun. 2003, 2091-2101. (c) Power, P. P. Organometallics 2007, 26, 4362-4372. (d) Rivard, E.; Power, P. P. Inorg. Chem. 2007, 46, 10047-10064. (e) Nagendran, S.; Roesky, H. W. Organometallics 2008, 27, 457-492. (f) Wang, Y.; Robinson, G. H. Chem. Commun. 2009, 5201-5213. (g) Mizuhata, Y.; Sasamori, T.; Tokitoh, N. Chem. Rev. 2009, 109, 3479-3511. (h) Fischer, R. C.; Power, P. P. Chem. Rev. 2010, 110, 3877-3923. (i) Mandal, S. K.; Roesky, H. W. Chem. Commun. 2010, 46, 6016-6041. (j) Asay, M.; Jones, C.; Driess, M. Chem. Rev. 2011, 111, 354-396. (k) Power, P. P. Acc. Chem. Res. 2011, 44, 627-637. (1) Wang, W.; Robinson, G. H. Dalton Trans., 2011; Epub ahead of print, DOI: 10.1039/C1DT11165E.

(2) Phillips, A. D.; Wright, R. J.; Olmstead, M. M.; Power, P. P. $\underline{\text { I.Am. }}$ Chem. Soc. 2002, 124, 5930-5931.

(3) (a) Fischer, R. C.; Pu, L.; Fettinger, J. C.; Brynda, M. A.; Power, P. P. I. Am. Chem. Soc. 2006, 128, 11366-11367. (b) Peng, Y.; Fischer, R. C.; Merrill, W. A.; Fischer, J.; Pu, L.; Ellis, B. D.; Fettinger, J. C.; Herber, R. H.; Power, P. P. Chem. Sci. 2010, 1, 461-468.

(4) Jambor, R.; Kašná, B.; Kirschner, K. N.; Schürmann, M.; Jurkschat, K. Angew. Chem. 2008, 120, 1674-1677; Angew. Chem., Int. Ed. 2008, 47, 1650-1653.

(5) Jones, C.; Bonyhady, S. J.; Holzmann, N.; Frenking, G.; Stasch, A. Inorg. Chem. 2011; Epub ahead of print, DOI: 10.1021/ic200682p.

(6) Green, S. P.i.Jones, C.; Stasch, A. Science 2007, 318, 1754-1757.

(7) (a) Power, P. P. Chem. Commun. 2003, 2091-2101. (b) Lein, M.; Krapp, A.; Frenking, G. I. Am. Chem. Soc. 2005, 127, 6290-6299. (c) Jung, Y.; Brynda, M.; Power, P. P.; Head-Gordon, M. J. Am. Chem. Soc. 2006, 128, 7185-7192. (d) Takagi, N; Nagase, S. Organometallics 2007, 26, 469-471. (e) Takagi, N; Nagase, S. Organometallics 2001, 20, $5498-5490$.

(8) (a) Nagendran, S.; Sen, S. S.; Roesky, H. W.; Koley, D.; Grubmüller, H.; Pal, A.; Herbst-Irmer, R Organometallics 2008, 27, 5459-5463. (b) Sen, S. S.; Jana, A.; Roesky, H. W.; Schulzke, C. Angew. Chem. 2009, 121, 8688-8690; Angew. Chem., Int. Ed. 2009, 48, 8536-8538. (c) Sen, S. S.; Kritzler-Kosch, M. P.; Nagendran, S.; Roesky, H. W.; Beck, T.; Pal, A.; Herbst-Irmer, R. Eur. J. Inorg. Chem. 2010, 5304-5311.

(9) Wingerter, S.; Gornitzka, H.; Bertermann, R.; Pandey, S. K.; Rocha, J.; Stalke, D. Organometallics 2000, 19, 3890-3894.

(10) (a) Albrecht, M.; van Koten, G. Angew. Chem. 2001, 113, 3866-3898. Angew. Chem. Int. Ed. 2001, 40, 3750-3781. (b) van der Boom, M. E.; Milstein, D. Chem. Rev. 2003, 103, 1759-1792. (c) Hoogervorst, W. J.; Koster, A. L.; Lutz, M.; Spek, A. L.; Elsevier, C. Organometallics 2004, 23, 1161-1164. (d) Selander, N.; Szabó, K. J. Chem. Rev. 2011, 111, 2048-2076.

(11) Simon, P.; De Proft, F.; Jambor, R.; Růžička, A.; Dostál, L. Angew. Chem. 2010, 120, 1674-1677. Angew. Chem., Int. Ed. 2010, 49, 5468-5471.

(12) (a) Stalke, D. Chem. Soc. Rev. 1998, 27, 171-178. (b) Kottke, T.; Lagow, R. J.; Stalke, D. L. Appl. Crustallogr. 1996, 29, 465-468. (c) Kottke, T.; Stalke, D. I. Appl. Crvstallogr. 1993, 26, 615-619.

(13) (a) Hahn, F. E.; Wittenbecher, L.; Kühn, M.; Lügger, T.; Fröhlich, R. I. Organomet. Chem. 2001, 617-618, 629-634. (b) Jurkschat, K.; van Dreumel, S.; Dyson, G.; Dakternieks, D.; Bastow, T. J.; Smith, M. E.; Dräger, M. Polvhedron 1992, 11, 2747-2755.

(14) (a) Becke, A. D. J. Chem. Phys. 1993, 98, 5648-5652. (b) Weigend, F.; Ahlrichs, R. Phvs. Chem. Chem. Phvs. 2005, 7, 3297-3305. (c) Metz, B.; Stoll, H.; Dolg, M. I. Chem. Phvs. 2000, 113, 2563-2569.

(15) (a) Ab initio, DFT, and semiempirical electronic structure package, version 2.8 (2010). (b) Werner, H.-J.; Knowles, P. J.; Lindh, R.; Manby, F. R.; Schütz, M. MOLPRO, version 2010.1, a package of ab initio programs 2010; http://www.molpro.net.

(16) Grimme, S. I. Comput. Chem. 2006, 27, 1787-1799.

(17) Reed, A. E.; Weinhold, F. J. Chem. Phys. 1983, 78, 4066-4073.

(18) (a) Jastrzebski, J. T. B. H.; Grove, D. M.; Boersma, J.; van Koten, G.; Ernsting, J.-M. Magn. Reson. Chem. 1991, 29, S25-S30. (b) Harris, R. K.; Mann, B. E. NMR and the Periodic Table; Academic Press: London, 1978.
(19) Power, P. P. Nature 2010, 463, 171-177.

(20) (a) Masuda, J. D.; Schoeller, W. W.; Donnadieu, B.; Bertrand, G. Angew. Chem. 2007, 119, 7182-7185. Angew. Chem., Int. Ed. 2007, 46, 7052-7055. (b) Masuda, J. D.; Schoeller, W. W.; Donnadieu, B.; Bertrand, G. I. Am. Chem. Soc. 2007, 129, 14180-14181. (c) Back, O.; Kuchenbeiser, G.; Donnadieu, B.; Bertrand, G. Angew. Chem. 2009, 121, 5638-5641. Angew. Chem. Int. Ed. 2009, 48, 5530-5533. (d) Melaimi, M.; Soleilhavoup, M.; Bertrand, G. Angew. Chem. 2010, 122, 8992-9032. Angew. Chem. Int. Ed. 2010, 49, 8810-8849. (e) Martin, D.; Soleilhavoup, M.; Bertrand, G. Chem. Sci. 2011, 2, 389-399.

(21) (a) Xiong, Y.; Yao, S.; Brym, M.; Driess, M. Angew. Chem. 2007, 119, 4595-4597. Angew. Chem. Int. Ed. 2007, 46, 4511-4513. (b) Sen, S. S.; Khan, S.; Roesky, H. W.; Kratzert, D.; Meindl, K.; Henn, J.; Stalke, D.; Demers, J.-P.; Lange, A. Angew. Chem. 2011, 123, 2370-2373. Angew. Chem. Int. Ed. 2011, 50, 2322-2325. (c) Khan, S.; Michel, R.; Sen, S. S.; Roesky, H. W.; Stalke, D. Angew. Chem. 2011; Epub ahead of print, DOI: 10.1002/ange.201105610; Angew. Chem., Int. Ed. 2011; Epub ahead of print, DOI: 10.1002/anie.201105610.

(22) (a) Schumann, H. Angew. Chem. 1969, 81, 970-983. Angew. Chem., Int. Ed. Engl. 1969, 8, 937-950. (b) Schumann, H.; Köpf, H.; Schmidt, M. Z. Anorg. Allg. Chem. 1964, 331, 200-205. (c) Schumann, H.; Köpf, H.; Schmidt, M. Chem. Ber. 1964, 97, 1458-1463. (d) Mathiasch, B.; Dräger, M. Angew. Chem. 1978, 90, 814-815. Angew. Chem. Int. Ed. Engl. 1978, 17, 767-768.

(23) Su, H. L.; Xie, Y.; Li, B.; Liu, X.; Qian, Y. T. J. Solid State Chem. 1999, 146, 110-113.

(24) (a) Power, P. P. Appl. Organomet. Chem. 2005, 19, 488-493. (b) Cui, C.; Olmstead, M. M.; Fettinger, J. C.; Spikes, G. H.; Power, P. P. L. Am. Chem. Soc. 2005, 127, 17530-17541. (c) Peng, Y.; Ellis, B. D.; Wang, X.; Fettinger, J. C.; Power, P. P. Science 2009, 325, 1668-1670. (d) Summerscales, O. T.; Wang, X.; Power, P. P. Angew. Chem. 2010, 122, 4898-4890. Angew. Chem., Int. Ed. 2010, 49, 4788-4790.

(25) (a) Bouška, M.; Dostál, L.; Rǔžička, A.; Beneš, L.; Jambor, R. Chem.-Eur. I. 2011, 17, 450-454. (b) Bouška, M.; Dostál, L.; De Proft, F.; Ružička, A.; Lyčka, A.; Jambor, R. Chem.-Eur. I. 2011, 17, 455-459.

(26) (a) Scherer, O. J.; Hilt, T.; Wolmershäuser, G. Organometallics 1998, 17, 4110-4112. (b) Holschumacher, D.; Bannenberg, T.; Ibrom, K.; Daniliuc, C. G.; Jones, P. G.; Tamm, M. Dalton Trans. 2010, 39, 10590-10592.

(27) Dräger, M.; Mathiasch, B. Angew. Chem. 1981, 93, 1079-1080. Angew. Chem. Int. Ed. Enol. 1981, 20, 1029-1030.

(28) (a) Fox, A. R.; Wright, R. J.; Rivard, E.; Power, P. P. Angew. Chem. 2005, 117, 7907-7911. Angew. Chem., Int. Ed. 2005, 44, 77297733. (b) Bezombes, J.-P.; Hitchcock, P. B.; Lappert, M. F.; Nycz, J. E. Dalton Trans. 2004, 499-501.

(29) (a) Niecke, E.; Rüger, R; Krebs, B. Angew. Chem. 1982, 94, 553-554. Angew. Chem., Int. Ed. Engl. 1982, 21, 544-545. (b) Riedel, R.; Hausen, H.-D.; Fluck, E. Angew. Chem. 1985, 97, 1050. Angew. Chem., Int. Ed. Engl. 1985, 24, 1056-1057.

(30) Schulz, T.; Meindl, K.; Leusser, D.; Stern, D.; Graf, J.; Michaelsen, C.; Ruf, M.; Sheldrick, G. M.; Stalke, D. J. Appl. Crystallogr. 2009, 42, 885-891.

(31) SAINT v7.68A; Bruker: Madison, 2008.

(32) Sheldrick, G. M. SADABS 2008/1; Bruker: Göttingen, 2008.

(33) Sheldrick, G. M. Acta Crystallogr., Sect. A 2008, 64, 112-122. 